\title{
Managing service quality by managing the service customer
}

\author{
Krishna K. Govender \\ Department of Business Management, University of Transkei, Private Bag X1, Unitra, 5117 Republic of South Africa
}

Received June 1998

\begin{abstract}
The need to manage service quality is becoming more urgent as links between service quality and business performance is becoming apparent. By breaking away from the traditional focus on the service employee, this article sheds light on strategies to manage service quality by managing the service customer. A survey was conducted among a sample of commercial bank customers to determine the effects of two types of socialization strategies on their perception of service quality. It was ascertained that by means of formal and informal socialization tactics. service firm managers could influence their customers' perception of the overall service quality as well as the employee service quality. Empirical evidence also supports the view that an organizational climate which supports service has a positive impact on the customers' perception of the employee service quality. The implications of these findings for service organization managers are discussed, and the opportunities for future research are also identified.
\end{abstract}

\section{Introduction}

Researchers (Lovelock \& Young, 1979: 168-178; Silpakit \& Fisk, 1985: 117; Schneider \& Bowen, 1995: 3) have argued that it is possible to improve service productivity by changing consumer behaviour and expectations. By allowing the customer to 'participate' in the service production process, service managers could improve the productivity of their operations. Customer 'participation' rather than customer 'contact' emphasizes the active role consumers play in the service encounter (Silpakit \& Fisk, 1985: 117).

Furthermore, researchers (Lovelock \& Young, 1979: 167-178; Mills \& Morris, 1986: 726-735; Schneider \& Bowen, 1995: 85; Wikstrom, 1996: 1-8) have pointed out that service customers could be considered as 'partial employees' of the service organization to increase service productivity. Since service customers often take on the role of 'partial' employees during the service encounter, it is important for the service organization to ascertain what management practices could be used to ensure that the customers have the competencies to perform their role as co-producers of the service.

Zeithaml. Parasuraman \& Berry (1990: 91) suggested a number of ways by which the service performance gap could be closed, inter alia, the provision of role clarity in job descriptions and quality standards, and informing employees about what is expected of them and what the goals, objectives, strategies and philosophy of the organization are. These suggestions imply the need for organizational socialization of the service employees. Organizational socialization is the process by which employees learn, appreciate, and internalize an organization's goals, values, social knowledge, and expected behaviours (Allen \& Meyer, 1990: 847; Jones, 1986: 263; Van Maanen \& Schein, 1979: 212; Wagner \& Hollenbeck, 1996: 284; Ashforth \& Saks, 1996: 149).

Some researchers (Dubinsky, Howell, Ingram \& Bellenger, 1986: 192-207; Feldman, 1976: 64-80; Hartline \& Ferrel, 1993) have examined the process of organizational socialization as it pertained to employees of service organizations. Due to the participatory nature of the role played by the service customers, that of a partial employee, it had been suggested that the process of socialization might also be considered as it pertains to the service customer (Mills \& Morris, 1986: 735; Kelley, Skinner \& Donnelly, 1990: 2; Schneider \& Bowen, 1995: 85-87). Although a great deal of conceptual and empirical work has been done regarding the socialization of employees of work organizations, the process of organizational socialization and its impact upon the employees and customers involved in the service encounter has only received limited attention (Kelley et al., 1992: 164; Hartline \& Ferrel. 1993: 1-2).

In view of the aforementioned, this research examines the effects of two types of organizational socialization tactics, namely formal and informal, on the service customers ${ }^{\circ}$ perception of service quality.

\section{Brief theoretical review}

The organizational socialization of the services customer had been discussed to a lesser extent by Bowen \& Schneider (1985), Mills (1986), and Bowen (1986). More recently, Schneider \& Bowen (1995: 88) adopting a Human Resources Management (HRM) perspective have argued that the service customer should be sucialized into the organization. Furthermore, Kelley (1987: 65) on the basis of customer organization membership notion developed by Barnard (1948) and Parsons (1970), maintains that the service customer is a member of the service organization in the sense that he provides resources to the service organization. The resources provided by the customer ranges on a continuum of tangibility, from intangible (information) to tangible (labour). However, Kelley (1987: 76) cautions that the active role of 'partial' employee played by the service customer results in the introduction of uncertainty in the service production process.

Kelley et al. (1992: 197) cites various researchers (Mills \& Moberg, 1985; Mills, 1986; Mills \& Morris. 1986) who contend that the process of organizational socialization is one method available to the service organization for reducing customer-introduced uncertainty. Therefore. prior to performing the role of 'part-time' employee in the service 
organization the service customer must have the necessary abilities. skills. and training. as well as accurate role expectations. Several researchers (Solomon. Surprenant. Czepiel \& Gutman. 1985: 99-111; Lovelock \& Young, 1979: 168178) also maintain that the role of the customer in the service encounter is composed of a set of learned behaviour acquired through the process of socialization.

Various researchers (Start \& Fondas, 1992: 69; Wagner \& Hollenbeck. 1996: 287) argue that socialization tactics influence the role orientations that newcomers ultimately adopt. However. Ashforth \& Saks (1996: 149-150) remark that despite the cogency of this typology, research on the tactics has been relatively scarce.

Van Maanen \& Schein (1979: 213) identified various socialization tactics or strategies, which include collective versus individual socialization. sequential versus random socialization. fixed versus variable socialization, guided versus unguided socialization, formal versus informal socialization. and investive versus divestive socialization. Formality is the degree to which socialization takes place apart from the ongoing work of the organization. During formal socialization, (new) employees are separated from others while they learn about the organization and their tasks (Van Maanen \& Schein. 1979 as cited by Wagner \& Hollenbeck. 1996: 288). Through informal socialization. (new) employees interact with more experienced employees. become integrated into their work groups. and learn on the job. Thus formal socialization allows the employees to see and learn what the organization wants them to learn; informal socialization allows employees to experience the organization on their own terms.

\section{Organizational socialization-service quality}

Studies (Schneider \& Bowen. 1995: 88) have suggested that the socialization of customers into the service organization may impact upon customer retention, motivation, and performance through alteration of the behaviour of the customer. Solomon et al. (1985: 94-111) have proposed that when customers and service employees 'read from a common script' (both are appropriately socialized into the organization). the service encounter will be more satisfying to both. In view of this, it is hypothesized that:

H1: Formal organizational socialization (FS) of service customers is positively associated with the overall service quality (SQUAL) as perceived by the customers

H2: Informal organizational socialization (IS) of service customers is negatively associated with the overall service quality as perceived by the customers.

Researchers (Ennew. Reed \& Martin. 1993: 59: Cronin \& Taylor. 1994: 125). in support of Gronroos (1990: 16). assen that in a service. the consumer is not only interested in 'what he receives as an outcome of the production process but in the process itself. Cronin \& Taylor (1994: 125-131) coined the term 'service performance' (SERVPERF), to highlight the importance of the process by which the service is delivered. Considering the aforementioned, it is hypothesized that:
H3: The service customers' perception of the overall service quality is positively associated with their perception of the employee service quality.

In the light of $\mathrm{H} 3$, it is also hypothesized that:

H4: Formal organizational socialization of service customers is positively associated with the employee service quality (EQUAL) as perceived by the customers.

H5: Informal organizational socialization of service customers is negatively associated with the employee service quality as perceived by customers.

The literature (below) suggests that effects of (the type) organizational socialization on service quality is indirect or mediated through other variables, inter alia, the customers' role perception and their perception of the organizational climate for service. Thus it is necessary to explore these apparent relationships.

Organizational socialization - role perception - service quality

Various researchers (Singh, 1993: 12; Michaels \& Dixon, 1994: 63; Singh, Vebreke \& Rhoads, 1996: 69) agree that when an individual has gained an appropriate understanding of his or her role and the roles of the other members of the role set, it is possible to formulate accurate role expectations. Furthermore, some researchers (Mills, 1986: 155; Kelley et al., 1992: 16; Schneider \& Bowen. 1995: 77) concur that in order for service employees (and service customers) to learn their roles and be able to form accurate role expectations for the service encounter, they must be socialized into the organization.

In the light of the above, the following hypotheses are proposed

Hla: Formal organizational socialization of service customers is negatively associated with the role ambiguity (RA) experienced by the customers.

H2a: Informal organizational socialization of service customers is positively associated with the role ambiguity (RA) experienced by the customers.

Hlb: Formal organizational socialization of service customers is negatively associated with the role conflict (RC) experienced by the customers.

$\mathrm{H} 2 \mathrm{~b}$ : Informal organizational socialization of service customers is positively associated with the role conflict experienced by the customers.

Lysonski (1982: 242-246) ascertained that role ambiguity has a negative influence on service quality. On the other hand, Nel. Boshoff \& Mels (1994: 8) established that role ambiguity which was modeled as being responsible for Gap 3 (the service delivery gap), did not influence Gap 5 (the service quality gap). However. Boshoff \& Mels (1995 23-42) ascertained that role conflict has a negative influence on organizational commitment and thus indirectly influences service quality. Tait (1996: 266) also found that role ambiguity affects service employee performance which may spill over to the perceptions of service quality on the part of the customers. In order to shed more light on the relationship between service quality and role. the following hypotheses are proposed: 
H6: The service customers' perception of the overall service quality is negatively associated with their level of role conflict.

H7: The service customers' perception of the overall service quality is negatively associated with the their level of role ambiguity.

H8: The service customers' perception of the employee service quality is negatively associated with their level of role ambiguity.

H9: The service customers' perception of the employee service quality is negatively associated with their level of role conflict.

Researchers (Behrman \& Perreault, 1984: 18; Boshoff \& Mels, 1994: 28) have found that role conflict and role ambiguity are positively correlated. To shed light on the relationship between role conflict and role ambiguity as it pertains to the service customer, it is hypothesized that

H10: The role ambiguity experienced by the service customer is positively associated with the role conflict experienced by the customer.

H11: The role conflict experienced by the service customer is positively associated with the role ambiguity experienced by the customer.

\section{Organizational socialization - organizational climate -} service quality

Bowen \& Cummings (1990: 4) maintain that the intangibility of services makes it difficult for management, employees and customers to assess service output and service quality. Consequently, an organization's overall 'climate for service', the atmospherics or feel of the setting is very important in shaping both customers' and front-line employees' attitude about the process and outcome of service delivery. Once customers arrive in the service facility, their on-site attitudes and behaviours are added to employee's as ingredients affecting organizational effectiveness.

Schneider (1980: 52-65) proposed that the climate for service created in an organization, including how the service is delivered, is critical for the service unit's effectiveness. Service excellence, Berry et al. (1989: 17) maintain, springs from leadership and organizational culture; 'characteristics which cannot be purchased from a store'. Researchers (Robbins, 1993: 611; Srinath, 1993: 29; Jones, 1986: 262-279) have argued that perceptions of the organizational climate and culture are a result of organizational socialization. In order to shed more light on the relationship between organizational socialization and the organizational climate, it is hypothesized that:

HIc: Formal organizational socialization of service customers is positively associated with the organizational climate (OC) for service as perceived by the customers.

$\mathrm{H} 2 \mathrm{c}$ : Informal organizational socialization of service customers is negatively associated with the organizational climate for service as perceived by the customers.

Furthermore, Schneider, Gunnarson \& Niles-Jolly (1994: 18) assert that employees (and customers) observe what happens to them (and around them), and draw conclusions about the organization's priorities. These perceptions provide employees with 'direction' and 'orientation' about where they should focus their energies and competencies. Although it may be argued that there are similarities between the constructs 'organizational climate' and 'customer orientation', it is necessary to stress that organizational climate for service is a perceptual process regarding the whole organization, whereas, customer orientation focusses on the individual employee and his hehaviour towards the customer. Since service quality is in the delivery, it is the interaction between the service deliverer and the consumer that determines service quality for the consumer.

Organizations can only indirectly control the interaction or 'service encounter' because of the simultaneous nature of production and consumption. Thus, in the absence of direct control of the service encounter, it is posited that the climate or organizational practices and procedures that communicate service as top priority will succeed in delivering high quality service. In view of the aforementioned, it is also hypothesized that:

\section{H12: The organizational climate for service as perceived} by the service customers is positively associated with their perception of the overall service quality.

H13: The organizational climate for service as perceived by the service customers is positively associated with their perception of the employee service quality.

\section{Organizational climate - role perception}

Schultz (1982: 445) explains the organizational climate in terms of the role theory. He describes role ambiguity as a situation that arises when the employee's work role, that is, the scope and responsibility of the job and what others expect of him or her, is so poorly structured as to be uncertain and ill-defined. This occurs when a person is not sure exactly what to do in executing job-related activities. Role ambiguity may also prohibit an individual from experiencing a sense of accomplishment, because the individual is unclear about what ought to be accomplished (Rowland \& Ferris, 1982: 402). The process of organizational socialization results in role learning and gaining an appreciation of the organizational culture and climate (Schein, 1990; as cited by McNabb \& Sepic, 1995: 373) on the part of the individual. In view of the aforementioned, it is hypothesized that:

H14: The organizational climate for service as perceived by the service customers is negatively associated with the role ambiguity experienced by the customers.

H15: The organizational climate for service as perceived by the service customer is negatively associated with the role conflict experienced by the customers.

The hypothesized relationships $(\mathrm{H} 1-\mathrm{H} 15)$ are depicted in the proposed model reflected in Figure 1.

\section{Research objectives}

This research addresses the following objectives: 


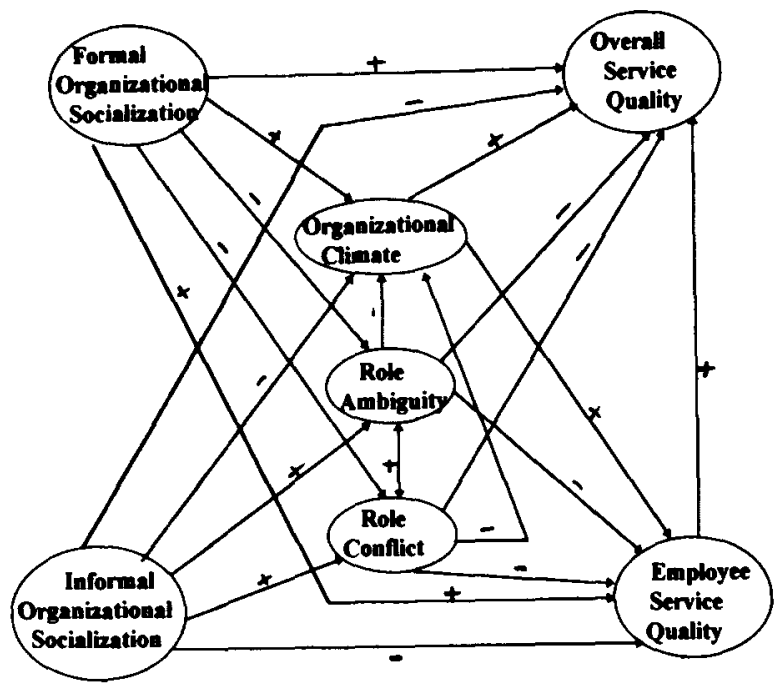

Figure 1 Hypothesized model

- the development of a questionnaire with instruments to measure the type of socialization, the organizational climate for service and the role perception of the service customers;

- assessing the validity and reliability of the measuring instruments: and

- fitting the theoretical model in Figure 1 to the empirical data to enable statistical inferences to be made of hypotheses $\mathrm{H1}-\mathrm{H} 15$.

\section{Research design}

The survey method was employed to obtain data from customers of three major commercial banks in South Africa. The questionnaires were distributed by front-line hank employees (excluding tellers) who had meaningful encounters with bank customers. A covering letter explaining the purpose of the research, as well as stamped, selfaddressed envelopes were provided. The bank employees were requested to hand questionnaires to every third customer with whom they interacted for at least five minutes. The rationale for choosing every third customer was to introduce a 'sense of randomness' into the sample, a procedure which has been endorsed by previous researchers (Danaher \& Mattsson, 1993: 8; Naumann \& Giel, 1995: 207-209).

\section{Sample and sampling procedure}

A combination of convenience and judgmental sampling (Parasuraman, 1991: 546-548; Naumann \& Giel, 1995: 201: Churchill, 1995: 579; Meidan, 1996: 53) was employed to survey 1000 bank customers.

After three months, only 200 customer questionnaires (20\%) were returned. However, after editing, only 166 customer questionnaires were usable. Thus the overall response was $16.6 \%$. The poor customer response rate can be attributed to the research method and because customers could not be 'forced' to complete and return the questionnaires. Furthermore, employees were unable to trace the customers to whom they had given questionnaires, since this was done randomly. As a follow-up, branch managers were requested to put up notices requesting customers to complete and return the questionnaires to the researcher.

\section{Data analysis}

To empirically evaluate the hypothesized relationships the computer programme RAMONA (Brown \& Mels, 1990) was used. RAMONA, which is an improvement on LIS. REL, not only tests for significant deviations from zero for all parameters, but also provides for measures of fit of the data to a hypothesized model. By specifying an analysis based on sample correlation matrix with maximum likelihood estimation, the research model wats fitted to the observed data.

\section{Research instrument}

The type of organizational socialization as perceived by the bank customers was measured with a five-point Likert scale with anchors of (1) strongly disagree, (2) disagree, (3) neither agree nor disagree (neutral), (4) agree, (5) strongly agree. The questions which attempted to determine the type of organizational socialization were adapted from the questionnaire developed by Jones (1986: 262-279) which was based on the theoretical work of Van Maanen \& Schein (1979). The questionnaire comprised of a nine-item instrument, four of which attempted to measure 'formal' socialization.

Throughout the instrument, a five-point scale was used because the pre-test revealed that respondents could not make fine mental distinctions with respect to whatever was being measured.

This strategy is supported by Parasuraman (1992: 427428) who asserts that for accurate measurements, a large number of scale positions are needed when a single-item scale is used rather than when a multiple-item scale is used.

To measure the customers' perception of the organizational climate, a 22-item, five-point Likert scale with anchors of (5) strongly agree and (1) strongly disagree was developed based upon an adaptation of Schneider \& Bowen's (1985: 423-437; 1995: 182-183) and Kelley's (1987: 126) scale. Kelley's (1987: 121) scale was developed around the exploratory research by Parasuraman et ah (1985: 41-52).

Despite its popular use (Boshoff \& Mels, 1995: 25-32; Tait, 1996: 256-259), the role conflict and ambiguity scales of Rizzo, House \& Lirtzman (1970: 150-163) was not used is this study. This was due to research (King \& King, 1990: 51-53; Hartline \& Ferrel, 1993: 47; Shepherd \& Fine. 1994: 57) which cast doubt on the validity of these scales. Instead the conflict and ambiguity scales developed by Chonko, Howell \& Bellenger (1986: 35-48) were adapted for this research.

In order to ascertain information about role conflict, service customers were asked to indicate the agreement between themselves and their banks on a five-point scale ranging from 1 (no agreement) to 5 (complete agreement). This section of the questionnaire consisted of two items. For the role ambiguity scale, bank customers were asked to indicate how certain they were about each of six items 
using a scale ranging from 1 (completely uncertain) to 5 (completely certain).

In most previous research, service quality has been measured as the difference between customer's expectations of service quality and the actual perceptions they have about service quality using the SERVQUAL scale which was originally designed by Parasuraman et al. (1988: 13-40). However, recent research (Babakus \& Boller, 1992: 253268; Carman. 1990: 55-58; Buttle, 1996: 8-32; Nel, Pitt \& Berthon, 1997: 113) has uncovered a number of deficiencies in the SERVQUAL scale. The deficiencies range from problems associated with difference scores, the use of positively and negatively worded items, and its validity.

In view of the deficiencies, an alternative scale (named SQUAL) hased on the 22-items of the SERVQUAL instrument was used in the present study. The SQUAL scale combines expectations and perceptions into one measure by asking customers whether certain aspects of service quality exceeded or fell short of expectations. This approach which was adopted by Hartline \& Ferrel (1993: 4849) was recommended by Carman (1990: 55), Cronin \& Taylor (1992: 55-68), and Parasuraman, Zeithaml \& Berry (1994: 201-230). Service customers were asked to rate each of the 22 items on a scale ranging from 1 (worse than expected) to 5 (better than expected).

By selecting only those items pertaining to the employee' from the SERVQUAL questionnaire, a 16-item instrument (Appendix 1) was developed to measure the employee service quality (EQUAL). Service customers were required to indicate their dis/agreement with each of the 16 items, where 1 indicated strongly disagree and 5 indicated strongly agree.

\section{Pilot testing and refinement of measuring instruments}

A pilot study was conducted among 50 customers in a branch of a major commercial bank. After a two-week period only 11 customer questionnaires were returned. Detailed statistical analysis of this data was not possible because any attempts, for example chi-square $(x 2)$ was not possible as Cochran's rules (Cochran, 1954: 417-451) regarding low cell values were being violated.

From the pilot study it became evident that the researcher would have very little control over the customer response. since all customers preferred to complete the questionnaires at home and not in the bank or in the presence of the hank employee. The aforementioned was expected, since customers who have spent time in queues, would not be willing to 'waste' more time in the bank. It also became apparent from the pilot study that respondents were ignoring negatively worded questions. In the final questionnaire, the negatively worded items were rephrased.

\section{Empirical findings \\ Reliability}

Stepwise Reliability Analysis (Willie, 1996) was performed on the various measuring instruments using the computer programme SAS PROC.CORR (SAS Institute, 1990). In Stepwise Reliability Analysis (SRA), individual items are deleted from the various measuring instruments if this action improves the overall reliability of the particular
Table 1 Cronbach alpha coefficients of measuring instruments

\begin{tabular}{lcc}
\hline Instrument & Original coefficient & Final coefficient \\
\hline Formal socialization & 0.807 & 0.807 \\
Informal socialization & 0.763 & 0.847 \\
Role ambiguity & 0.852 & 0.861 \\
Role conflict & 0.886 & 0.886 \\
Organizational climate & 0.950 & 0.949 \\
Overall service quality & 0.970 & 0.966 \\
Employee service quality & 0.960 & 0.933 \\
\hline
\end{tabular}

measuring instrument as measured by its Cronbach's coefficient alpha (Cronbach. 1951: 297-334). The process is repeated until all the measuring instruments possess an acceptable level of reliability. Bless \& Higson-Smith (1995: 135) assert that an instrument which produces a coefficient of reliability of at least 0.7 is favoured hy most social scientists. It is evident from Table I that the latent variables are measured with acceptable levels of reliability (internal consistency) by their respective adapted measuring instruments.

\section{Validity}

As an initial step to address the question of validity. the measure development paradigms recommended by various researchers (Churchill, 1995: 534-539; Bless \& HigsonSmith, 1995: 136-138; Parasuraman. 1991: 442-443) was closely followed during the development of the scales. Thereafter, after having determined the Cronbach's coefficients alpha, Stepwise Exploratory Factor Analysis (Willie, 1996) was performed to ascertain the discriminant and construct validity of the measuring instruments. In each step of the analysis. BMDP4M (Frane. Jennrich \& Sampson. 1993) was used to perform a maximum likelihood factor analysis with a direct quartimin rotation (Jennrich \& Sampson. 1966: 313-323) of the unrotated factor matrix. It is evident from Table 2 that the measuring instruments possess acceptable levels of discriminant and construct validity since they load heavily with loadings above 0.4 (Rummel. 1967: 444-480) on one factor.

The model depicted in Figure 1 was fitted to the ohserved data by specifying an analysis based on the sample correlation matrix with maximum likelihood estimation. The resulting maximum likelihood estimates with their associated significance information in terms of $p$ values are also shown in Figure 2.

Figure 2 shows that contrary to the hypothesized view. both formal and informal socialization experienced by the customers exert a significant positive influence on their perception of the overall service quality and the employee service quality. Furthermore. the quality of service delivered by the service employee is the most important determinant of the customers' perception of the overall service quality delivered by the service organization. It is also evident from Figure 2 that both formal and informal socialization of the customers are significantly positively correlated with the organizational climate. More specifically, the better the formal and informal communication between the 


\begin{tabular}{|c|c|c|c|c|c|c|c|}
\hline hem & $\begin{array}{c}\text { Factor } 1 \\
\text { FS } \\
\end{array}$ & $\begin{array}{c}\text { Factor } 2 \\
\text { IS }\end{array}$ & $\begin{array}{c}\text { Factor } 3 \\
\text { RA }\end{array}$ & $\begin{array}{c}\text { Factor } 4 \\
\text { RC }\end{array}$ & $\begin{array}{c}\text { Factor } 5 \\
\text { OC }\end{array}$ & $\begin{array}{l}\text { Factor } 6 \\
\text { SQLAL }\end{array}$ & $\begin{array}{l}\text { Factor } 7 \\
\text { EQLAL }\end{array}$ \\
\hline FSI & 0.057 & 0.009 & 0.133 & 0.001 & 0.212 & 0.063 & $0.427^{*}$ \\
\hline FS6 & 0.052 & 0.019 & -0.030 & 0.014 & -0.060 & -0.101 & $0.829 *$ \\
\hline FS & -0.012 & 0.008 & 0.009 & -0.007 & 0.037 & 0151 & $0.721^{*}$ \\
\hline IS: & -0079 & 0.049 & -0.006 & 0.031 & $0.900 *$ & 0.017 & -0.049 \\
\hline IS4 & 0.115 & -0.051 & 0.035 & -0.030 & $0.732=$ & -0.019 & 0.060 \\
\hline$R+2$ & 0.062 & 0015 & -0.033 & $0.638^{*}$ & 0.027 & 0.032 & -0.126 \\
\hline$R A^{3}$ & -0.014 & -0.014 & -0.018 & e.992* & -0.036 & -0.028 & $0.0 \div 6$ \\
\hline R+4 & -0.054 & -0.011 & 0.122 & $6.813^{*}$ & -0.030 & 0.071 & $6: 4$ \\
\hline$R+6$ & 0.146 & 0.013 & -0.007 & $0.430^{*}$ & 0.240 & 0.029 & 0.116 \\
\hline RCI & -004 & 0.005 & -0.039 & 0.079 & 0.064 & $0.842^{*}$ & 0.070 \\
\hline $\mathrm{RC}=$ & 0.025 & 0.025 & 0.029 & -0.017 & -0.057 & $0.899 *$ & -0.040 \\
\hline OCI & 0.102 & $0.902^{*}$ & -0.043 & 0.011 & 0.006 & -0.019 & 0.013 \\
\hline$O C=$ & 0.046 & ๑.915* & -0.042 & 0.005 & 0.012 & 0.068 & -0.036 \\
\hline $\mathrm{OC}^{3}$ & -0.147 & 6.941* & 0.074 & 0.041 & -0.006 & -0.029 & 0.056 \\
\hline OCA & $0.0 \leq 0$ & $0810^{\circ}$ & 0.071 & -0.060 & -0.011 & 0.020 & -0.020 \\
\hline SOI & essi* & 0.053 & 0.020 & 0.085 & 0.046 & -0.033 & 0.019 \\
\hline SQ2 & 0.924: & -0.036 & 0.048 & 0.022 & 0.009 & 0.013 & -0.041 \\
\hline SQ3 & $\operatorname{esc} 7 *$ & 0.025 & 0.090 & -0.039 & -0.022 & 0.068 & 0.065 \\
\hline SO4 & ex44: & 0.026 & -0.013 & -0.020 & -0.008 & -0.001 & 0.029 \\
\hline EQ: & 0.040 & 0092 & 0.810 & -0.006 & 0.015 & -0.003 & -0.046 \\
\hline $\mathrm{EQ}^{3}$ & 0.006 & -0.049 & $0.972 *$ & 0.037 & -0.013 & 0.017 & -0.000 \\
\hline EQ4 & 0.038 & 0.028 & $0.842 *$ & -0.005 & 0.011 & -0.019 & 0.026 \\
\hline
\end{tabular}

service organization and its customers, the 'warmer' the organizational climate. Furthermore formal socialization and informal socialization are significantly correlated with both the role ambiguity and the role conflict experienced by the service customers. This means that the better the formal and informal socialization between the service organization and its customers. the lower will be the level of role ambiguity and role conflict experienced by the customers and vice versa.

The measures of fit of the model depicted in Figure 2 are provided in Table 3. The Root Mean Square Error of Approximation (RMSEA) of 0.068 is less than 0.08 which suggests that the model provides a reasonable fit to the data (Broune \& Mels. 1990). This contention is further supported by the fart that the expected cross validation index ICVI, for the model of $\mathbf{3 . 0 4 6}$ is less than 3.345 for the saturated model

Based on the staustical analysis reflected in Figure 2. the empincal results are summarized in terms of the hypothees $\mathrm{HI}-\mathrm{H} 15$ as shown in Table 4 .

\section{Discussion of empirical findings}

The most revealing finding is that. both formal and informal socialization exert a positive influence on the customers" perception of the overall service quality and the employee service quality. Previous research (Kelley, 1987:
156-160) merely supports the hypothesis of a positive relationship between the 'level' or 'degree' of organizational socialization achieved by the customers and their perception of the organizational climate and service quality.

The customers ${ }^{\circ}$ perception of the employee service quality emerged as the most important determinant of the overall service quality. Employee service quality which is akin to 'functional' quality (Gronroos. 1990: 16) has been identified (Cronin \& Taylor, 1994: 125) as an important component of service quality. Researchers (Zeithaml \& Bitner, 1996: 117) concur that the employee effor is viewed positively by the customers in their evaluation of their satisfaction with the service.

Although it emerged that the customers perception of the organizational climate did not directly influence their perception of the overall service quality. it also became apparent that the organizational climate is a very important determinant of the employee service quality. Since the employee service quality is the most important determinant of the overall service quality. it may be assumed that the ofganizational climate indirectly influences the customers perception of the overall service quality. Furthermore. both formal and informal socialization are correlated with the organizational climate and the customers' role perception. 


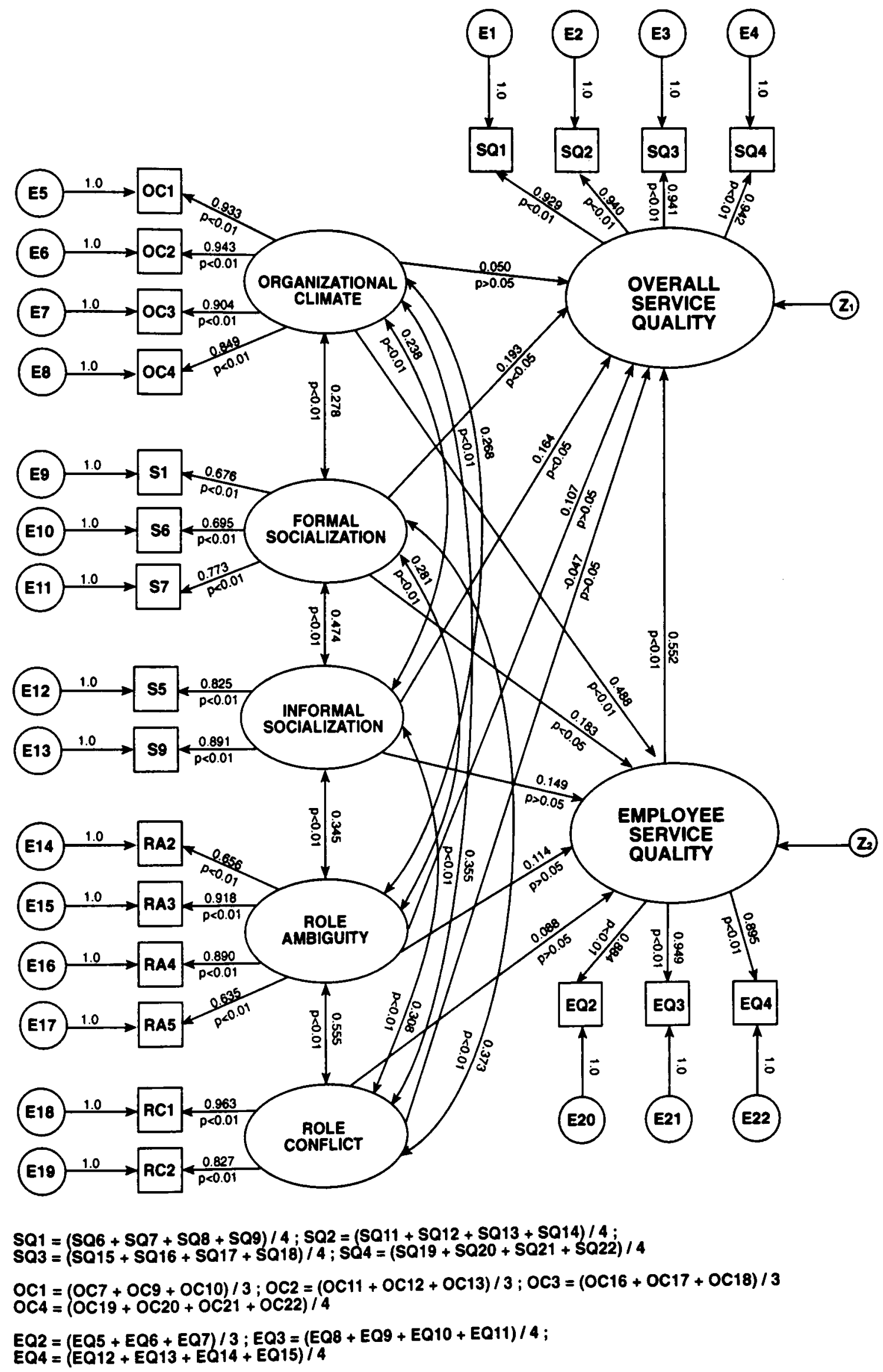

Figure 2 Empirical evaluation of the hypothesized model: service customer-service quality

The organizational climate as perceived by the customers is also positively correlated with their role perceptions as well as with their perception of the employee service quality. 


\begin{tabular}{ll}
\hline Table 3 Measures of fit of the causal customer model \\
\hline Sample discrepancy function & $=2.161$ \\
Sample discrepancy function value & \\
Population discrepancy function value & $=0.931$ \\
Bias adjusted point estimate & $=(0.636 ; 1.273)$ \\
$90 \%$ confidence interval & $=0.068$ \\
Root mean square error of approximation point estimate & $=(0.056 ; 0.079)$ \\
$90 \%$ confidence interval & $=3.046$ \\
Expected cross validation index point estimate (modified AIC) & $=(2.751 ; 3.389)$ \\
$90 \%$ confidence interval & $=3.341$ \\
Cross validation (modified AIC) for saturated model & $=3.56 .60$ \\
Chi-square test statistic & \\
Exceedance probabilities: & $=0.000$ \\
Ho: perfect fit (RMSEA $=0.0)$ & $=0.008$ \\
Ho: close fit (RMSEA.LE. 0.050$)$ & $=203$ \\
Degrees of freedom &
\end{tabular}

Since the customers' perception of the employee service quality is the most important determinant of the overall service quality, the customers' perception of their role may also indirectly influence their perception of the overall service quality.

Moreover, it became apparent that customers are socialized (may acquire banking knowledge and skills) from both formal and informal sources, as both (sources) are significantly correlated $(0.555 ; \mathrm{p}<0.01)$. Since customers interact with other customers (Langeard, Bateson, Lovelock \&
Eiglier, 1981: 82) during service delivery, it may be assumed that this is a source of 'informal' socialization.

\section{Managerial implications}

Since the process of socialization can be controlled to a large extent by the organization, management should ensure that customers are effectively socialized. Through effective socialization, it may be possible to manage the service expectations of the service customers and indirectly

\begin{tabular}{|c|c|c|c|c|}
\hline Hypotheses & Description & $\begin{array}{l}\text { Hypothesized } \\
\text { influence }\end{array}$ & $\begin{array}{c}\text { Actual } \\
\text { influence }\end{array}$ & Conclusion \\
\hline $\mathrm{HI}$ & FS $\rightarrow$ SQUAL & positive & positive & accepted \\
\hline $\mathrm{H} 2$ & IS $\rightarrow$ SQUAL & negative & positive & rejected \\
\hline $\mathrm{H} 3$ & EQUAL $\rightarrow$ SQUAL & positive & positive & accepted \\
\hline H4 & FS $\rightarrow$ EQUAL & positive & positive & accepted \\
\hline H5 & IS $\rightarrow$ EQUAL & negative & positive & rejected \\
\hline Hla & $\mathrm{FS} \rightarrow \mathrm{RA}$ & negative & negative & accepted \\
\hline $\mathrm{H} 2 \mathrm{a}$ & IS $\rightarrow$ RA & positive & negative & rejected \\
\hline HIb & $\mathrm{FS} \rightarrow \mathrm{RC}$ & negative & negative & accepled \\
\hline $\mathrm{H} 2 \mathrm{~b}$ & $I S \rightarrow R C$ & positive & negative & rejected \\
\hline H6 & $\mathrm{RC} \rightarrow \mathrm{SQUAL}$ & negative & NC & NC \\
\hline H7 & $\mathrm{RA} \rightarrow \mathrm{SQUAL}$ & negative & NC & $\mathrm{NC}$ \\
\hline $\mathrm{H8}$ & $\mathrm{RA} \rightarrow \mathrm{EQUAL}$ & negative & NC & NC \\
\hline H9 & $\mathrm{RC} \rightarrow \mathrm{EQUAL}$ & negative & NC & NC \\
\hline HIO & $R A \rightarrow R C$ & positive & positive & accepted \\
\hline HII & $\mathrm{RC} \rightarrow \mathrm{RA}$ & positive & positive & accepled \\
\hline HIC & $\mathrm{FS} \rightarrow \mathrm{OC}$ & positive & positive & accepted \\
\hline $\mathrm{H} 2 \mathrm{c}$ & IS $\rightarrow \mathrm{OC}$ & negative & positive & rejected \\
\hline $\mathrm{HI2}$ & $O C \rightarrow$ SQUAL & positive & NC & NC \\
\hline $\mathrm{HI} 3$ & OC $\rightarrow$ EQUAL & positive & positive & accepted \\
\hline $\mathrm{HI4}$ & $\mathrm{RA} \rightarrow \mathrm{OC}$ & negative & negative & accepted \\
\hline HIS & $\mathrm{RC} \rightarrow \mathrm{OC}$ & negative & negative & accepled \\
\hline
\end{tabular}


manage their perceptions of service quality. Furthermore the process of organizational socialization provides a means for the service organization to help customers develop more accurate role expectations and this would result in customers performing their roles better which could contribute to the delivery of higher levels of service quality. Since it may be difficult to control the information which customers receive from 'informal' sources, banks should endeavour to provide as much information as possible by way of 'formal' sources, for example pamphlets and newsletters.

Consumer behaviour research on how customers acquire their perception of their consumption and production roles may also benefit service managers trying to develop able 'partial employees'. Although customers are a source of input uncertainty relative to the diversity of their demands and their disposition to participate, the service organization could also influence the customers.

Since service customers often take on the role of 'partial' employees during the service encounter, it is important for the service organization to ascertain what management practices can be used to ensure that the customers have the competencies to perform their role as co-producers of the service. Since customers pass judgement on the business at contact points, contact points should be managed. Management should think about the many opportunities there are to score points with customers.

Furthermore, since service encounters are first and foremost 'social encounters' services marketers must truly understand the underlying bases of their businesses. In view of the rapid changing technology, in financial services marketing there are limited opportunities to impress the customer. Thus contact points should be treated as opportunities, the opportunity to create a favourable impression must be cherished and not let to slip by.

The unit of analysis in marketing should be the relationship, the mutual recognition of some special status between exchange partners that is the result of a successful series of encounters. Since service firms are often in direct contact with their customers, they have the ability to build parallel economic and personal ties with their customers. Such strong ties would enable the firm to better serve its customers and to deter competitive efforts to win those customers away.

The consumption and production demands of our economy are partly served through an understanding of certain issues raised in this study. The lagging productivity of the service sector could be improved by utilizing the information and labour supplied by the customers. These are some of the gains from managing customers as human resources in service organizations.

\section{Limitations of the study}

The customer questionnaires were completed at home and it is possible that the encounter experience may not be as vivid so as to enable the customers to respond as accurately as possible. A possible suggestion would be to try to interview them immediately after the encounter. This may also contribute to an improved response rate.

\section{Future research}

To increase the generalizability of the findings of this study, future research might involve the replication of this study in a variety of service settings, industries and organizations.

Furthermore, research on the effects of the different socialization tactics, other than formal and informal socialization, could serve to shed more light on how management could effectively socialize its service customers.

\section{References}

Allen. N.J. \& Meyer, J.P. 1990. Organizational socialization tactics: a longitudinal analysis of links to newcomers' commitment and role orientation, Academy of Management Journal. 3.3: 847-858.

Ashforth, B.E. \& Sacks, A.M. 1996. Socialization tactics: longitudinal effects on newcomer adjustment, Academy of Management Journal, 30(1): 149-178

Babakus, E. \& Boller, G.W. 1992. An empirical assessment of the SERVQUAL scale. Journal of Business Research. 24(2): 253268.

Behrman, D.N. \& Perreault, W.D. Jr. 1984. A role stress model of the performance and satisfaction of industrial salespersons. Journal of Marketing, 48: 355-377.

Bless, C. \& Higson-Smith. C. 1995. Fundamentals of social research methods: an African perspective. 2nd ed. Kenwyn. Cape Town: Juta.

Berry. L.L., Bennett. D.R. \& Brown. C.W. 1989. Service qualin: a profit strategy for financial institutions. Homewood. III: Dow Jones-Irwin.

Boshoff, C. \& Mels. G. 1994. A causal model to evaluate the relationships among supervision, role stress. organizational commitment and internal service quality. European Journal of Marketing, 29(2): 23-42.

Bowen. D.E. \& Cummings. T.G. 1990. Suppose we took services seriously. In Bowen, D.E., Chase. R.B. \& Cummings. T.G. eds Senice management effectiveness: balancing strategy, organization and human resources, operations, and marketing. San Francisco: Jossey-Bass. pp.85-122.

Bowen. D.E. \& Schneider, B. 1985. Boundary-spanning-role employees and the service encounter: some guidelines for management research. In Czepiel. J.A.. Solomon. M.R. \& Surprenant. C.F. eds. The senice encounter. Lexington. MA: Lexington Books. pp.72-148.

Browne. M.W. \& Mels. G. 1990. RAMONA PC user'; guide. Unpublished Report. Pretoria: Human Sciences Research Council.

Buttle, F. 1995. SERVQUAL: review, critique and research agenda. European Joumal of Marketing. 30(1):8-32.

Carman. J.M.. 1990. Consumer perceptions of service quality: an assessment of the SERVQUAL dimensions. Journal of Retailing. 66(1): 35-5.5.

Chonko, L.B.. Howell, R.D. \& Bellenger. D.N. 1986. Congruence in sales force evaluations: relations to sales force perceptions of conflict and ambiguity. Joumal of Personal Selling andSales Management, 6: 35-48.

Churchill, G.A. Jr. 1995. Marketing research: methodological foundations. 6th ed. Florida: Dryden.

Cochran. W.G. 1954. Some methods for strengthening the common chi-square test. Biometrics. 10: 125-14.3.

Cronbach. L.J. 1951. Coefficient alpha and the internal structure of tests, Psychometrica. 16(3): 297-334.

Cronin. J.J., Jr. \& Taylor. S.A.. 1992. Measuring service quality: a re-examination and extension. Joumal of Marketing. 56: 55-68. 
Cronin. J.J. Jr. \& Taylor, D.A. 1994. SERVPERF versus SERVQUAL: reconciling performance based and perceptions-minus expectations measurement of service quality, Journal of Marketing, 58: 125-131.

Danaher. P.J. \& Mattson, J. 1994. Customer satisfaction during the service delivery process, European Journal of Marketing, 28(5): $5-16$.

Dubinsky, A.J.. Howell, R.D., Ingram, T.N. \& Bellenger, D.N. 1986. Sales force socialization. Journal of Marketing, 50(4) 192-207.

Ennew. C.T.. Reed. G.V \& Binks, M.R. 1993. Importance-performance analysis and the measurement of service quality, European Journal of Marketing, 27(2): 59-70.

Feldman. D.C. 1976. A contingency theory of socialization, AdIninistration Science Quarterly: 21: 433-4.52.

Frane, J.. Jenrich, R.I. \& Sampson, P.F. 1990. 4M-factor analysis. In Dixon, W.J. et al. eds. BDMP statistical software manual. Berkeley: University of California, 1.

Gronroos, C., 1990. Service management and marketing. Managing the moments of truth in service competition. Massachusetts Lexington Books.

Hartline, M.D. \& Ferrel, O.C. 1993. Service quality implementation: the effects of organizational socialization and managerial actions on customer-contact employee behaviours, Marketing Science litstitute Report No. 93-122. Cambridge, MA: Marketing Science Institute.

Jenrich. R.I. \& Sampson, P.F. 1966. Rotation of simple loadings, Psychometrica, 31: 313-323.

Jones, G.R. 1986. Socialization tactics, self-efficacy, and newcomer's adjustment to organizations, Academy of Management Journal. 29(2): 262-279.

Kelley. S.W. 1987. Managing service quality: the organizational socialization of the service employee and service customer. Unpublished DBA dissertation. Lexington, Kentucky: University of Kentucky.

Kelley, S.W.. Skinner, S.J. \& Donnelly, J.H. 1990. Customer participation in service production and delivery, Journal of Retailing. 66(3): 315-335.

Kelley, S.W.. Skinner, S.J. \& Donnelly, J.H. 1992. Organizational socialization of service customers. Journal of Business Research, 25(3): 197-214.

King. L.A. \& King, D.W. 1990. Role conflict and ambiguity: a critical assessment of construct validity, Psychological Bulletin, 107(I): 48-64.

Langeard. E.. Bateson, J.E.G., Lovelock, C.H. \& Eiglier, P. 1981. Services marketing: new insights from consumers and managers. Marketing Science Institute Report No. 81-104. Cambridge. Massachusetts: Marketing Science Institute.

Lovelock. C.H.. \& and Young, R.F. 1979. Look to customers to improve productivity, Harvard Business Review, 57: 168-178.

Lysonski. S.J.. 1982. Behavioural effects of boundary spanning on the product manager. In Walker, B.D., Bearden, W.O., Darden, W.R., Murphy, P.E.. Nevin, J.R., Olson, J.C. \& Weitz, B.A. eds. An assessment of marketing thought and practice. Chicago: American Marketing Association. Proceedings Series, pp.242246.

Meidan. A. 1996. Marketing financial services. Gt. Britain: Macmillan.

McNabb. D.E. \& Sepic, F.T. 1995. Culture, climate, and total quality management: measuring readiness for change, Public Productivin Management, 18(4): 369-385.

Michaels. R.E. \& Dixon. A.L. 1994. Sellers and buyers on the boundary: potential moderators of role stress-job outcome relationships. Journal of the Academy of Marketing Science, 22(1): 62-73.
Mills, P.K. 1983. The socialization of clients as partial employees of service organizations. Working Paper, University of Santa Clara.

Mills, P.K. \& Morris, J.H. 1986. Clients as partial employees of service organizations: role development in client participation Academy of Management Review, 11( 4): 726-735.

Nauman, E. \& Giel, K. 1995. Customer satisfaction measurement and management: using the voice of the customer. Cincinnati, Ohio: Thompson

Nel, D., Boshoff, C. \& Mels, G. 1994. A re-assessment of the extended service quality model. Paper delivered at the Sixth Annual Conference of The Southern African Institute of Management Scientists. University of Western Cape: Belville.

Nel, D., Pitt, L.F. \& Berthon, P.R. 1997. The SERVQUAL instrument: reliability and validity in South Africa, South African Journal of Business Management, 28(3): 113-122.

Parasuraman, A. 1991. Marketing research. 2nd. ed. Massachusetts: Addison-Wesley.

Parasuraman, A., Zeithaml, V.A. \& Berry, L.L. 1994. A reassessment of expectations as a comparative standard in measuring service quality: implications for future research. Journal of Marketing, 58: 111-124.

Rentsch, J.R. 1990. Climate and culture: interaction and qualitative differences in organizational meanings, Journal of Applied Psychology, 75(6): 376-387.

Rizzo, J.R., House, R.J. \& Lirtzman, S.I. 1970. Role contlict and ambiguity in complex organizations, Administrative Science Quarterly, 15: 150-163.

Robbins, S.P. 1993. Organizational behaviour. 6th. ed. PrenticeHall.

Rowland, K.M. \& Ferris, G.R. 1982. Personnel management. Massachusetts: Allyn and Bacon.

Rummel, R.J. 1967. Understanding factor analysis, Journal of Conflict Resolution, 11: 444-480.

SAS Institute Inc. 1990. User's guide, Release 6.03. Cary, N.C.: SAS Institute Inc.

Schneider, B. 1980. The service organization: climate is crucial, Organizational Dynamics, 9: 52-65.

Schneider, B. \& Bowen, D.E. 1985. Employee and customer perceptions of service in banks: replication and extension, Journal of Applied Psychology, 70(3): 423-433.

Schneider, B., Gunnarson, S.K. \& Niles-Jolley, K. 1994. Creating the climate and culture of success, Organizational Dynamics, 23(1): 17-30.

Schneider, B. \& Bowen, D.E. 1995. Winning the service game. Boston: Harvard Business School Press.

Schultz, D.P. 1982. Psychology and indusiry today: introduction to industrial and organizational psychology. 3rd. ed. New York Macmillan.

Shepherd, C.D. \& Fine, L.M. 1994. Scaling and measurement: role conflict and role ambiguity reconsidered, Journal of Personal Selling and Sales Management, 14(2): 57-65.

Silpakit, P. \& Fisk, R.P. 1985. Participatizing the service encounter: a theoretical framework. In Bloch, T.M., Upah, G.D. \& Zeithaml, V.A. eds. Services marketing in a changing environment. Chicago: American Marketing Association, pp. 142-155.

Singh, J. 1993. Boundary role ambiguity: facets, determinants and impacts, Journal of Marketing, 57: 11-31.

Singh, J., Vebreke, E. \& Rhoads, G.K. 1996. Do organizational practices matter in role stress processes? A study of direct and moderating effects for marketing-orientated boundary spanners, Journal of Marketing, 60: 69-86.

Smith, R.A. \& Houston, M.J. 1983. Script-based evaluations of satisfaction with services. In Berry, L.L., Shostack G.L. \& Upah, G.D. eds. In emerging perspectives on services marketing. Chicago: American Marketing Association: 59-62. 
Solomon, M.R., Surprenant, C., Czepiel, J.A. \& Gutman, E.G. 1985. A role theory perspective on dyadic interaction: the service encounter. Journal of Marketing, 49: 99-111.

Srinath. M., 1993. The organizational climate of university libraries, Libran Management, 14(1): 28-30.

Starr, J.A. \& Fondas, N. 1992. A model of entrepreneurial socialization and organizationformation, Entrepreneurship: theory and practice. US: Baylor University, pp.67-77.

Tait, M. 1996. Die invloed van geselekteerde bestuursveranderlikes op dic diensgehalte by finansiële instellings: ' $n$ interne bemarkingsperspektief. Unpublished DCom thesis. Port Elizabeth: University of Port Elizabeth.

Van Maanen. J. \& Schein, E.H. 1979. Towards a theory of organizational socialization. In Staw, B.M. ed. Research in organiza- tional behaviour. Greenwich, CT: JAI, 1: 209-264.

Wagner, J.A. \& Hollenbeck, J.R. 1996. Management of organizational behaviour. Englewood Cliffs, New Jersey: Prentice-Hall.

Wikstrom, S. 1996. The customer as co-producer, European Journal of Marketing, 30(4): 6-19.

Willie A.S. 1996. A stepwise procedure for the empirical assessment of latent variable models. Unpublished MSc dissertation. Port Elizabeth: University of Port Elizabeth.

Zeithaml, V.A., Parasuraman, A. \& Berry, L.L. 1990. Delivering quality service: balancing customer perceptions and expectations. New York: The Free Press.

Zeithaml, V.A. \& Bitner, M.J. 1996. Service marketing. New York: McGraw-Hill.

\section{Appendix 1}

With regard to the BANK EMPLOYEE who served you, please indicate the degree of your agreement or disagreement with the following: 1 = STRONGLY DISAGREE; 2 = DISAGREE; 3 = NEUTRAL; 4 = AGREE; 5 = STRONGLY AGREE.

THE BANK EMPLOYEE:

\begin{tabular}{|c|c|c|c|c|c|c|}
\hline EQI & Was neatly attired & 1 & 2 & 3 & 4 & 5 \\
\hline EQ2 & Understood vour needs & 1 & 2 & 3 & 4 & 5 \\
\hline EQ3 & Was willing to help & 1 & 2 & 3 & 4 & 5 \\
\hline EQ4 & Was courteous & $\mathbf{I}$ & 2 & 3 & 4 & 5 \\
\hline EQS & Was prompt & 1 & 2 & 3 & 4 & 5 \\
\hline EQ6 & Gave you personal attention & I & 2 & 3 & 4 & 5 \\
\hline EQ7 & Treated your transaction confidentially & 1 & 2 & 3 & 4 & 5 \\
\hline EQ8 & Was able to answer queries & 1 & 2 & 3 & 4 & 5 \\
\hline EQ9 & Delivered on promises & 1 & 2 & 3 & 4 & 5 \\
\hline EQI0 & Had your best interest at heart & 1 & 2 & 3 & 4 & 5 \\
\hline EQII & Was sincere in solving your problem/s & $\mathbf{1}$ & 2 & 3 & 4 & 5 \\
\hline EQ12 & Performed the service right the first time & 1 & 2 & 3 & 4 & 5 \\
\hline EQ13 & Was never too busy to respond to your requests & 1 & 2 & 3 & 4 & 5 \\
\hline $\mathrm{EQ} 14$ & Told you exactly when the service will be performed & 1 & 2 & 3 & 4 & 5 \\
\hline EQ15 & Made you feel safe in conducting your transaction & 1 & 2 & 3 & 4 & 5 \\
\hline EQ16 & Used language which you could understand & 1 & 2 & 3 & 4 & 5 \\
\hline
\end{tabular}

